\title{
Demographic factors and dietary diversity of chepang children of Dhading, Nepal
}

\begin{abstract}
Background: Dietary diversity refers the numbers of food items consumed by the people. Number of food items, meal frequency and food quantity people consume depends upon the age group, health status, and level of awareness, socio-economic status and access on food. Dietary diversity is directly related to the nutritional status which is very important for the growth and development of children. There are various factors associated with the dietary diversity, so the study was conducted to identify the demographic factors and dietary diversity of Chepang children of Dhading district of Nepal.
\end{abstract}

Objective: The aim of the study is to find out factors associated with dietary diversity among Chepang children.

Methods and materials: A cross sectional study was conducted among the 347 mothers and their 6-24 months' children. Mothers were the primary respondents for the survey. Structured questionnaire survey was done to collect the quantitative data. Statistical analysis was done to analyze the dietary diversity on the basis of demographic characteristic.

Results: The results found that $55.6 \%$ mothers fed their children $1-3$ items and $44.4 \%$ mothers fed four or more items within the 24 hours. There was no significant association by the gender, age, family types, HHs annual income with dietary diversity, but there was significant association between mother's education with dietary diversity.

Conclusion: Mothers' education was found as an important factor that should be promoted through the formal and informal education system. Knowledge and attitude of mother towards the important dietary diversity should be explored in the future research.

Keywords: Chepang, demographic factor, dietary diversity, children, nutrition
Volume 7 Issue 5 - 2018

\author{
Ghimire J \\ Texila American University, Guyana
}

Correspondence: Ghimire Jeeban, Ph D. Scholar, School of Public Health, Texila American University, Guyana, Tel: 977984I414889, Email jeeghimire@yahoo.com

Received: July 24, 2018 | Published: October 02, 2018

\section{Introduction}

Dietary diversity is a most critical epigenetic element that can influence nutritional status of people. Nutrition plays a noteworthy part in the development of the sensory system. Caring of children depends upon the knowledge, skill and practice of parents as well as other socio-economic factors. In some patriarchal society, son is more preferred and cared better than daughter. In such cases, daughter's nutritional status may be poor. Similarly, parents may give less attention and care to elder children than younger children. Besides that other factors like mother's education, family types and household annual income may effect in the dietary diversity of children. There are multifaceted reasons that causes under-nutrition. The various complex interactive factors that affects children's under-nutrition like socio-demographic, environmental, reproductive, institutional, social, cultural, economic, political and regional factors. ${ }^{1}$ Nutritional differences are thought about irregularly the higher commonness of under-nutrition; overweight and obesity or both, in indeterminate shameful social conditions, for example, poverty, starvation, illness and pestilence. ${ }^{2}$ Dietary and environmental, geological as well as ecological components assume a noteworthy part in children's nutritional status through a health maintenance. ${ }^{3}$ The dispositions of parental figures slanted toward maternal and child health mandates of applicable welfare associations and information procured amid a visit for antenatal administration can step by step bring down the danger of malady due to under-nutrition or under-sustenance and thus happening weaknesses. ${ }^{4} \mathrm{~A}$ few encompassing elements like atmosphere, climate, contamination, sickness and plague can add to lack of healthy sustenance, including starvation, drying out, pallor, cell dryness, hypoxemia and debility from neediness caused insufficient supplements of vital protein, water and sanitation, along these lines high infection load brings about a short stature or moderate development amid the age. Hindered kids who recouped well on account of better care demonstrated pick up of human capital results that were vaguely fundamental from conditions with non-hindered children. $^{5}$

The pervasiveness of issue, for example, early youth hindering and the quantity of individuals living in total destitution (absolute poverty) is used as an indicator of poor improvement of the same included place. Hindering in early childhood is caused by poor nourishment and disease instead of by hereditary contrasts. Poor children are more helpless against all lacking advancement let results and noteworthy development delays i.e. cognizance, dialect, physical and socioemotional side effects by socio-economic gradient was there apparent in a few under-developed nations. Children's advancement comprises of a few between subordinate spaces of neuro-psychology research including capacity of tactile engines, psychological mindset, and social-emotional affinities, which are all prone to be influenced because of the parameter of bio-substance fixings in blood being gotten from supply of fresh food. Further, other than sustenance, it is likely that natural elements, i.e., financial status, finding out about 
ecological changes, incitement of associating family at home, family estimate, repetitive disease and so on likewise assume vital part in mental advancement of any adolescent. The inconsistency between their current formative levels and what they would have accomplished in great sustaining condition with sufficient stimulant and nutritional provision shows the level of pick up and even misfortune in even loss in health potential accordingly. In later phases of childhood these concerned youthful will in this manner have poor levels of insight and instruction, both of which are connected to their ability of procuring a sustenance procedure. ${ }^{6}$ The country like African and Asian worlds who are well known for maternal and child malnutrition in low-income and middle-income generating countries encompasses both deprivation health nutrients and a rising up problem along with overweight and obesity. ${ }^{7}$ Nepal is a multiethnic, multicultural and multilingual country. Chepang is one ethnic group basically lives in the remote rural areas. They are categorized as 'the most marginalized' by the Government's indigenous authority, on the basis of a set of socio-economic indicators, such as population size, language, literacy rate, house type, landownership, occupation and access to education. These factors may cause in the dietary diversity practices of their children and their nutritional status. Many previous literatures have written that gitthas (wild tubers of Dioscorea bulbifera) and shoots of sisnoo (nettle, Urtica dioica) are the main source of food for Chepang to appease their appetite. So the study aims to identify the association between the demographic factors and dietary diversity of Chepang community.

\section{Method and material}

The study was conducted among the 6-24 months Chepang children of Dhanding district of Nepal. It was based on the crosssectional study applying descriptive and exploratory design. The study used the structured questionnaire survey to collect the data of demographic information and dietary diversity of Chepang community. Total 347 mothers and their children participated in the study. The purposive sampling technique was adopted to select the respondents because the target respondent of this study was mother having with 6-24 months' children so researcher had to identify such types of respondent purposively. The collected data were analyzed from the statistical software (SPSS 20 version) and presented in the numerical data. Chi-Square test was run to identify the association between the two variables.

\section{Ethics}

The study obtained ethical approval from the Nepal Health Research Council, Government of Nepal. Individually, verbal consent was obtained from all participants.

\section{Findings and Discussion}

This study focused on the collection and analysis of demographic information and dietary diversity of Chepang children. The details of collected data and results are interpreted below.

\section{Gender wise Dietary diversity of Chepang Children}

There was direct relationship between dietary diversity and nutritional status of children. The following table shows result of gender-wise dietary diversity of Chepang children. Out of 165 male children, 87 (52.7\%) were fed 1-3 items and 78 (47.3\%) were fed 4 and more items. Similarly, out of 182 female children, $106(58.2 \%)$ were fed 1-3 items and $76(41.8 \%)$ were fed 4 and more items. The result of Chi-square test shows that there was no significant correlation ( $p>0.05$, i.e. 0.302 ) between gender and prevalence of frequency of food items provided to the children. The result indicates that there was no gender discrimination in feeding practices while providing the number of food items (Table 1).

\section{Age wise Dietary diversity of Chepang Children}

The following table shows results of age-wise dietary diversity of Chepang children. Out of 66 (6-8 months) children, 43 (65.2\%) were fed 1-3 items and 23 (34.8\%) were fed 4 and more items. Similarly, out of 279(9-24 months) children, 149 (53.4\%) were fed 1-3 items and $130(46.6 \%)$ were fed 4 and more items. The result of Chi-square test shows that there was no significant correlation ( $p>0.05$, i.e. 0.084 ) between age and prevalence of frequency of food items provided to the children (Table 2).

\section{Mother's education and Dietary diversity of Chepang Children}

The following table shows relationship between mother's education level and dietary diversity of Chepang children. Table 3 shows that higher the education had more practice of dietary diversity. It is found that $67.5 \%$ illiterate mothers are feeding their children mostly 1-3 items. $48.4 \%$ literate mothers fed their children 1-3 items, but $51.6 \%$ fed 4 and more items of food. Similarly, $44.7 \%$ primary educated mothers fed their children 1-3 items of food, however, $55.3 \%$ feed 4 and more items. Nevertheless, $60.4 \%$ secondary level educated mothers fed 1-3 items of food to their children. On the other hand, $66.7 \%$ higher education level mothers fed their child 4 and more items. $100 \%$ of bachelor level educated mothers feed their children 4 and more items of food. It shows that education has direct relationship with knowledge of dietary diversity to the children. Result of Chisquare test shows that there is significant correlation $(p<0.05$, i.e. 0.008 ) between dietary diversity and mother's education level.

\section{Family Types and Dietary diversity of Chepang Children}

Family has an impact on dietary intake of children as an important food environment and family structures are changing and becoming more diverse. Thus, the following table shows results related with family structure and dietary diversity of Chepang children. The study found that $55.2 \%$ children from nuclear family were fed 1-3 items of food, and $56 \%$ children from joint family were fed 1-3 items food. The result of Chi-square test shows that there is no significant correlation $(\mathrm{p}>0.05$, i.e. 0.885$)$ between family structure and dietary diversity of Chepang children (Table 4).

\section{Household Annual Income and Dietary diversity of Chepang Children}

Household income is also considered one of the factors which can effect on the nutritional status of children. It is obvious that every parent want to feed their children as their knowledge, skill and effort but sometimes they become unable to feed adequate nutritional diet because of the low economic status. So, the study had studied the economic status of Chepang community and its association with nutritional status of their children. The data presented in Table 5 shows the association between households ( $\mathrm{HHs}$ ) annual income and dietary diversity of Chepang children. 91.7\% children were fed 1-3 items and only $8.3 \%$ were fed 4 and above items whose parents had up to $20000 /-$ annual income whereas $57.1 \%$ children were fed $1-3$ 
items and $42.9 \%$ were fed 4 and above items whose parents had more than 100000/- annual income. The data shows that the $60 \%$ parents whose income was between 21000-40000/- fed their children 4 and above items within the 24 hours. The statistical data shows that there was no significant association between the HHs annual incomes a dietary diversity of Chepang Children because the $p=.114$ which is greater than the .05 significant levels. The result indicates that there was no effect or any significant changes in the dietary diversity with the increasing of annual income.

Table I Gender wise dietary diversity of chepang children

Source: Field survey, 2018

\begin{tabular}{|c|c|c|c|c|c|c|c|}
\hline & & \multicolumn{4}{|c|}{ Gender } & \multirow{2}{*}{\multicolumn{2}{|c|}{ Total }} \\
\hline & & \multicolumn{2}{|l|}{ Boys } & \multicolumn{2}{|l|}{ Girls } & & \\
\hline & & Count & $\%$ & Count & $\%$ & Count & $\%$ \\
\hline \multirow{2}{*}{ Total food items } & I-3 Items & 87 & $52.7 \%$ & 106 & $58.2 \%$ & 193 & $55.6 \%$ \\
\hline & 4 and above items & 78 & $47.3 \%$ & 76 & $41.8 \%$ & 154 & $44.4 \%$ \\
\hline Total & & 165 & $100.0 \%$ & 182 & $100.0 \%$ & 347 & $100.0 \%$ \\
\hline \multicolumn{8}{|l|}{ Chi-Square Tests } \\
\hline & & \multicolumn{2}{|c|}{ Value } & df & \multicolumn{3}{|c|}{ Asymp. Sig. (2-sided) } \\
\hline Pearson Chi-Square & & \multicolumn{2}{|c|}{1.066} & I & \multicolumn{2}{|c|}{.302} & \\
\hline
\end{tabular}

Table 2 Age wise dietary diversity of chepang children

Source: Field survey, 2018

\begin{tabular}{|c|c|c|c|c|c|}
\hline & & & $\begin{array}{l}\text { Age Group } \\
\text { 6-8 Months }\end{array}$ & 9-24 Months & Total \\
\hline \multirow{4}{*}{ Total food items } & \multirow{2}{*}{ I-3 Items } & Count & 43 & 149 & 192 \\
\hline & & $\%$ & $65.2 \%$ & $53.4 \%$ & $55.7 \%$ \\
\hline & \multirow{2}{*}{4 and above items } & Count & 23 & 130 & 153 \\
\hline & & $\%$ & $34.8 \%$ & $46.6 \%$ & $44.3 \%$ \\
\hline \multirow{2}{*}{\multicolumn{2}{|c|}{ Total }} & Count & 66 & 279 & 345 \\
\hline & & $\%$ & $100.0 \%$ & $100.0 \%$ & $100.0 \%$ \\
\hline \multicolumn{6}{|l|}{ Chi-Square Tests } \\
\hline \multirow{2}{*}{\multicolumn{2}{|c|}{ Pearson Chi-Square }} & Value & $d f$ & Asymp. Sig. (2-sided) & \\
\hline & & 2.984 & .08 & .084 & \\
\hline
\end{tabular}

Table 3 Mother's education and dietary diversity of chepang children

Source: Field survey, 2018

\begin{tabular}{|c|c|c|c|c|c|c|c|c|}
\hline & & \multicolumn{7}{|c|}{ Mother education } \\
\hline & & Illiterate & Literate & Primary & $\begin{array}{l}\text { Secondary } \\
\text { level }\end{array}$ & $\begin{array}{l}\text { Higher } \\
\text { Secondary }\end{array}$ & Bachelor & Total \\
\hline \multirow{2}{*}{ I-3 Items } & Count & 83 & 45 & 34 & 29 & 2 & 0 & 193 \\
\hline & $\%$ & $67.5 \%$ & $48.4 \%$ & $44.7 \%$ & $60.4 \%$ & $33.3 \%$ & $0.0 \%$ & $55.6 \%$ \\
\hline \multirow{2}{*}{4 and above items } & Count & 40 & 48 & 42 & 19 & 4 & I & 154 \\
\hline & $\%$ & $32.5 \%$ & $51.6 \%$ & $55.3 \%$ & $39.6 \%$ & $66.7 \%$ & $100.0 \%$ & $44.4 \%$ \\
\hline Total & Count & 123 & 93 & 76 & 48 & 6 & I & 347 \\
\hline \multicolumn{9}{|l|}{ Chi-Square Tests } \\
\hline & \multicolumn{2}{|c|}{ Value } & \multicolumn{2}{|c|}{ df } & \multicolumn{2}{|c|}{ Asymp. Sig. (2-sided) } & & \\
\hline Pearson Chi-Square & \multicolumn{2}{|c|}{15.534} & \multicolumn{2}{|c|}{5} & \multicolumn{2}{|c|}{.008} & & \\
\hline
\end{tabular}

Table 4 Family structure and dietary diversity of chepang children

Source: Field survey, 2017

\begin{tabular}{|c|c|c|c|c|c|c|}
\hline & & & & \multicolumn{2}{|c|}{ Family Types } & \multirow{2}{*}{ Total } \\
\hline & & & & Nuclear & Joint Family & \\
\hline \multirow{4}{*}{ Food Items } & \multirow{2}{*}{ I-3 Items } & Count & & 100 & 93 & 193 \\
\hline & & $\%$ & & $55.2 \%$ & $56.0 \%$ & $55.6 \%$ \\
\hline & \multirow{2}{*}{4 and above items } & Count & & 81 & 73 & 154 \\
\hline & & $\%$ & & $44.8 \%$ & $44.0 \%$ & $44.4 \%$ \\
\hline \multirow{2}{*}{\multicolumn{2}{|c|}{ Total }} & Count & & $|8|$ & 166 & 347 \\
\hline & & $\%$ & & $100.0 \%$ & $100.0 \%$ & $100.0 \%$ \\
\hline \multicolumn{7}{|c|}{ Chi-Square Tests } \\
\hline \multirow{2}{*}{\multicolumn{2}{|c|}{ Pearson Chi-Square }} & Value & $d f$ & & \multicolumn{2}{|c|}{ Asymp. Sig. (2-sided) } \\
\hline & & .021 & I & & .885 & \\
\hline
\end{tabular}


Table $5 \mathrm{HH}$ annual income and dietary diversity of chepang children

Source: Field survey, 2018

\begin{tabular}{|c|c|c|c|c|c|c|c|c|}
\hline & & \multicolumn{7}{|c|}{ Income categories } \\
\hline & & $\begin{array}{l}\text { Up to } \\
20000\end{array}$ & $\begin{array}{l}21000- \\
40000\end{array}$ & $\begin{array}{l}41000- \\
60000\end{array}$ & $\begin{array}{l}61000- \\
80000\end{array}$ & $\begin{array}{l}81000- \\
100000\end{array}$ & $\begin{array}{l}\text { More than } \\
100000\end{array}$ & Total \\
\hline \multirow{2}{*}{ I-3 Items } & Count & II & 6 & 23 & 15 & 21 & 117 & 193 \\
\hline & $\%$ & $91.7 \%$ & $40.0 \%$ & $52.3 \%$ & $50.0 \%$ & $51.2 \%$ & $57.1 \%$ & $55.6 \%$ \\
\hline \multirow{2}{*}{4 and above items } & Count & 1 & 9 & 21 & 15 & 20 & 88 & 154 \\
\hline & $\%$ & $8.3 \%$ & $60.0 \%$ & $47.7 \%$ & $50.0 \%$ & $48.8 \%$ & $42.9 \%$ & $44.4 \%$ \\
\hline \multirow{2}{*}{ Total } & Count & 12 & 15 & 44 & 30 & 41 & 205 & 347 \\
\hline & $\%$ & $100.0 \%$ & $100.0 \%$ & $100.0 \%$ & $100.0 \%$ & $100.0 \%$ & $100.0 \%$ & $100.0 \%$ \\
\hline \multicolumn{9}{|l|}{ Chi-Square Tests } \\
\hline \multirow{2}{*}{\multicolumn{2}{|c|}{ Pearson Chi-Square }} & \multicolumn{2}{|c|}{ Value } & $\mathrm{df}$ & \multicolumn{3}{|c|}{ Asymp. Sig. (2-sided) } & \\
\hline & & \multicolumn{2}{|c|}{8.880} & 5 & \multicolumn{2}{|c|}{.114} & & \\
\hline
\end{tabular}

\section{Conclusion}

The study found that majority of parents $(55.6 \%)$ were providing the 1-3 items of food to their 6-24 months' children within the 24 hours in a day. From the analysis of gender of children, more boys were feed 4 items than the girl children from their parents. Similarly, 9-24 months children were more feed 4 items than the 6-8 months children. There was significant effect of mother's education on the dietary diversity of children. Educated mothers had provided the 4 items to their children whereas more illiterate mothers had provided only up to 3 items to their children. There was no any effect of family types and household annual income in dietary diversity practices of mothers. The result shows that level of knowledge and awareness of mother on the importance of dietary diversity to maintain the nutritional status of children is more important than the other demographic factors. ${ }^{8}$

\section{Recommendations}

There is need to identify the knowledge and attitude of mothers towards the importance of dietary foods and its minimum required items to their child's growth and development.

\section{Acknowledgements}

The author is grateful to Dr. Deepak Paudel for his overall guidance and to Dr. Tej Bahadur Karki for his support in this research and their endless encouragement and help. I would also like to thank the enumerators and other contributors. Finally, I extend my gratitude to the study participants involved in this study.

\section{Conflict of interest}

The author declares that they have no conflict of interest.

\section{References}

1. Asfaw M, Wondaferash M, Taha M, et al. Prevalence of undernutrition and associated factors among children aged between six to fifty nine months in Bule Hora district, South Ethiopia. BMC Public Health. 2015;15:41.

2. Perez-Escamilla R, Bermudez O, Buccini GS, et al. Nutrition disparities and the global burden of malnutrition. BMJ. 2018;361:2252.

3. Ashaba S, Rukundo GZ, Beinempaka F, et al. Maternal depression and malnutrition in children in southwest Uganda: a case control study. BMC Public Health. 2015;15:1303.

4. Al-sobaihi S, Nakamura K, Kizuki M. Undernutrition among children under 5years of age in Yemen : Role of adequate childcare provided by adults under conditions of food insecurity. Journal of Rural Medicine. 2016;11(2):47-57.

5. Undurraga EA, Behrman JR, Emmett SD, et al. Child stunting is associated with weaker human capital among native Amazonians. American Journal of Human Biology. 2018;30(1).

6. Das N, Choudhuri D, Ghosh A. Intelligence Quotient Development in Relation To Physical Growth, Development and Nutritional State in Early Childhood: a Systematic Review. World Journal of Pharmaceutical and Medical Research. 2017;3(6):116-123.

7. Black RE, Victora CG, Walker SP, et al. Maternal and child undernutrition and overweight in low-income and middle-income countries. The Lancet. 2013;382(9890):427-451.

8. Ali Naser I, Jalil R, Wan Muda WM, et al. Association between household food insecurity and nutritional outcomes among children in Northeastern of peninsular Malaysia. Nutrition Research and Practice. 2014;8(3):304-311. 